\title{
Bio contamination of surfaces and medical devices in controlled environment areas at a hospital in Morocco
}

\author{
Samira Jaouhar ${ }^{1,2^{*}}$, Abdelhakim El Ouali Lalami ${ }^{1,2}$, Khadija Ouarrak ${ }^{3}$, Jawad Bouzid ${ }^{4}$, Mohammed Maoulouaa ${ }^{3}$, and \\ Khadija Bekhti ${ }^{1}$ \\ ${ }^{1}$ Laboratory of Microbial Biotechnology\& Bioactive Molecules, Faculty of Science and Technology, Sidi Mohammed Ben University \\ Abdeallah Fez. BP 2202, Fes, Morocco. \\ ${ }^{2}$ Higher Institut of Nursing and Health Professions of Fez-Meknes. Regional Directorate of Health Fes-Meknes, El Ghassani Hospital, \\ Dhar El Mehraz, 30000 Fes, Morocco. \\ ${ }^{3}$ Medical Analysis Laboratory of the Meknes Hospital Center, Regional Health Department Fes-Meknes. \\ ${ }^{4}$ Hassan First University, Higher Institute of Health Sciences, Health sciences and technologies laboratory, Casablanca Road km 3, 5 \\ BP 555 Settat - Morocco.
}

\begin{abstract}
The hospital environment, especially medical devices and surfaces, represents a secondary reservoir for pathogens. This work aims to evaluate the microbiological quality of surfaces and medical equipment of controlled environment services (burn unit, operating room, and sterilization service) at a hospital in Meknes (center of Morocco). This study was carried out for three months (September-December of 2017). A total of 63 samples were taken by swabbing technique from different surfaces and medical equipment after bio-cleaning. Identification was performed according to conventional bacteriological methods and by microscopic observation for fungi. The study showed that $68 \%$ of the surface was contaminated. The operating room recorded a rate of $93 \%$ of contamination ( $p$-value $<0.01$ ), $83 \%$ for sterilization service, and $47 \%$ for burn unit. A percentage of $67 \%$ of the isolates were identified as Gram-positive bacteria against $32 \%$ Gram-negative bacteria ( $p$-value $<0.05$ ). Bacterial identification showed Coagulasenegative Staphylococci (45\%), Enterobacter cloacae (14\%), Micrococcus sp (10\%), Klebsiella pneumoniae, peptostreptococcus sp and Pseudomonas fluorescens ( $7 \%$ for each one), Escherichia coli, and Methicillin-resistant Staphylococcus aureus (5\% for each one). These results require corrective action represented by rigorous cleaning and disinfection procedures.
\end{abstract}

\section{Introduction}

The hospital environment is generally colonized by many opportunistic and pathogens microorganisms for humans [1]. The microorganisms can survive several days and months on moist and dry surfaces [2]. Hospital surfaces and medical devices could be contaminated by patients, caregivers' hands, or the environment $[3,4]$. This contamination depends on the time, the services, the patients, and the care techniques used [5]. The contamination level of hospital surfaces could be related to several factors such as the quality of cleaning, the life of a microorganism on an inert object, its adhesion to the surface, its ability to produce a biofilm [6], and its ability to withstand adverse conditions [7]. Bacterial species isolated from surfaces are not necessarily pathogenic. However, the flora resulting from human activity, such as cutaneous flora [Staphylococcus aureus] or mucous membrane bacteria, and certain bacterial species of hydrous flora (Pseudomonas aeruginosa) may be responsible for Health-care Associated Infections (HAI) [8,9]. Many types of pathogenic microorganisms have been found on hospital surfaces including Clostridium difficile $[10,11]$, Klebsiella sp [12,13], Staphylococcus aureus $[14,15]$ and Acinetobacter baumannii $[16,17]$. Several authors have confirmed the role of the hospital environment in HAI $[18,19]$. Therefore, microbiological monitoring of the environment of healthcare facilities is an essential measure for detecting environmental risk. The aim of this work, which was carried for the first time at a hospital in Meknes, was to examine the microbiological quality of surfaces and medical equipment of controlled environment services (burn unit, central block, and sterilization service). Therefore, the purpose of microbiological monitoring of the environment is (i) to examine the presence of nosocomial pathogens and (ii) to evaluate hygiene standards and disinfection practices [20 ]. This study will help decision-makers to develop an appropriate risk analysis strategy to control the risk associated with the hospital environment. 


\section{Material and methods}

\subsection{Study design}

We carried over three months (SeptemberDecember of 2017) the sampling of surfaces and equipment of burn unit, operating room, and sterilization service (controlled environment areas) in a hospital at Meknes. The choice of these services was based on the following criteria:

* French Standard (NF S 90 351-2013).

* The immune status of patients.

- Access to services.

\subsection{Sampling method}

The microbiological sampling of the surfaces was carried out by swabbing using sterile swabs previously moistened with a volume of $1 \mathrm{~mL}$ of BHI (Brain Heart Infusion) [21] [22 ]. The swabbing technique has been used in numerous studies $[17,13,23]$. The sampling of each critical point was repeated three times on the same surface. The samples were taken without human activity and after Bio cleaning except for the sterilization service [24].

\subsection{Analysis of samples}

For isolation, a volume of $10 \mu \mathrm{L}$ of each sample was inoculated on semi-selective media: Chapman (Staphylococcus and Micrococci), MacConkey (Enterobacteriaceae), Cetrimide (Pseudomonas aeruginosa), and Sabouraud (fungi). The Petri dishes of bacteria were incubated for 24 hours, 5 to 7 days for the fungi. The identification of bacteria was carried out according to conventional bacteriology methods. Fungi were identified by two fundamental examinations: macroscopic and microscopic [25].

\subsection{Data processing and analysis}

Data entry was using Microsoft Office Excel 2010 (version). The descriptive and the analytical part were realized using the XLSTAT extension. To give meaning to the results, we used the Chi-square test. $P$ value $<0.001, P$-value $<0.01, P$-value $<0.05$ were respectively considered highly significant, very significant, and significant.

\section{Results}

From 63 samples, $68 \%(n=43)$ of the samples were found positive. The operating room recorded a very high percentage of $93 \%$, followed by the Sterilization service with a percentage of $83 \%$, and finally the Burn unit (47\%) (Fig.1). The distribution is statistically very significant (Chi-square $=12.69, \mathrm{df}=$ 2 , p-value $<0.01$ ).

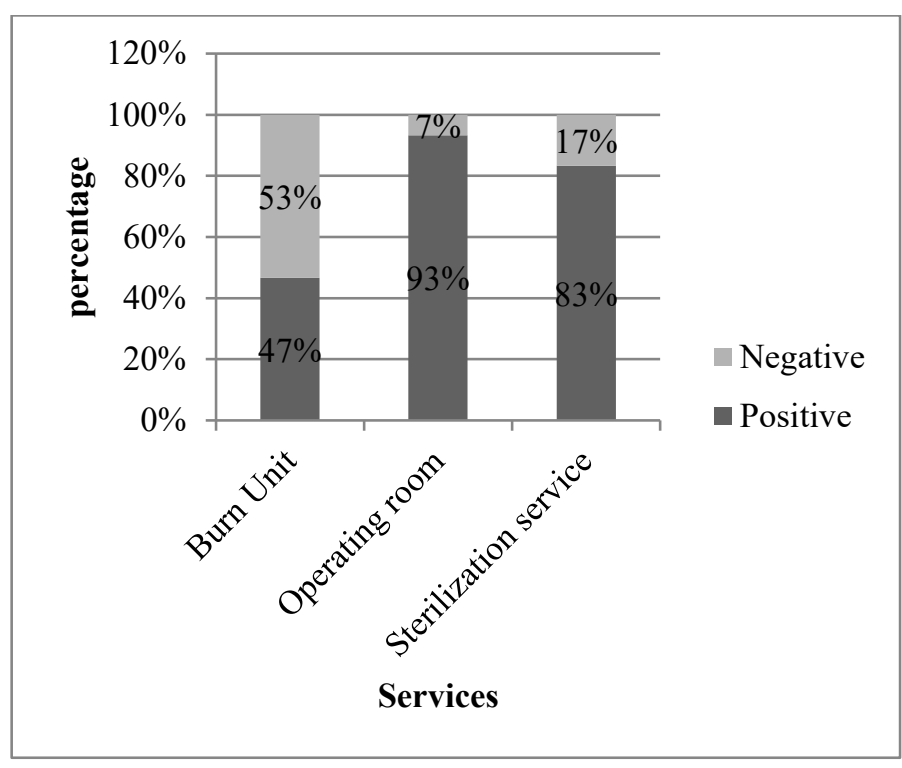

Fig. 1 Percentage of contamination by units.

Autoclave, surgical light, and anesthesia table are the most contaminated $(100 \%)$, followed by cart $(89 \%)$ and surfaces $(78 \%)$

(Fig.2).

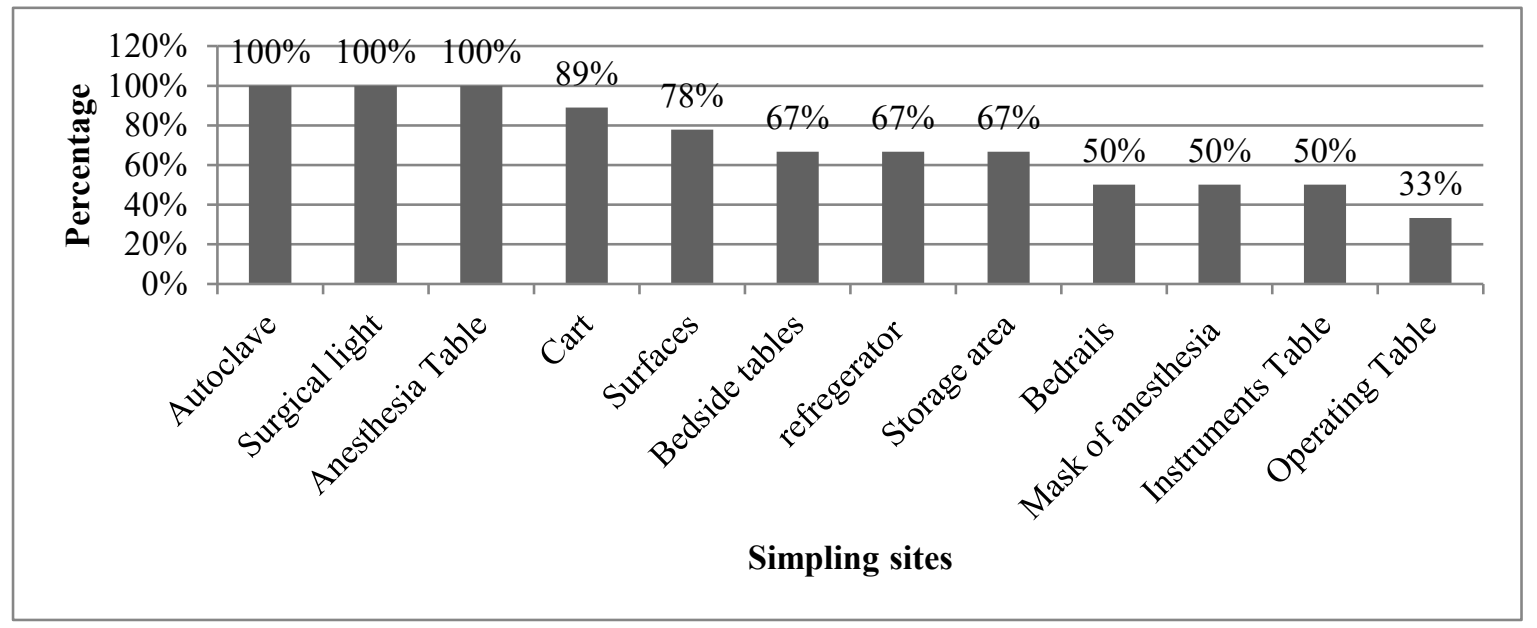

Fig. 2 Contamination rate of different sampling site 
Distribution of contamination by sampling sites is highly significant (Chi-square $=4150,172, \mathrm{df}=11, \mathrm{p}$ value $<0.001)$. A percentage of $98 \%$ of the isolates were bacteria, while fungi accounted for only $2 \%$. Almost two-thirds (67\%) of the isolated bacteria belong to Gram-positive bacteria against $32 \%$ of Gramnegative. The distribution of bacteria according to the Gram staining is statistically significant (chi-square = 7 , df $=1, p$-value $<0.05)$. Microbiological analysis showed that the bacteria to major nosocomial risk contaminate surfaces. Coagulase-negative
Staphylococci was the microorganism most often encountered (45\%), followed by Enterobacteriaceae [Escherichia coli (5\%), Enterobacter cloacae (14\%), and Klebsiella pneumoniae 7\%] with a percentage of $26 \%$ and Micrococcus sp with a percentage of $10 \%$. Peptostreptococcus spp and Pseudomonas fluorescens were represented by a percentage of $7 \%$ for each one. Finally, Methicillin-resistant Staphylococcus aureus has been present with a percentage of 5\% (Fig 3). The bacterial distribution is highly significant (Chi-square $=$ $32.28, \mathrm{df}=5$, $\mathrm{p}$-value $<0.001$ ).

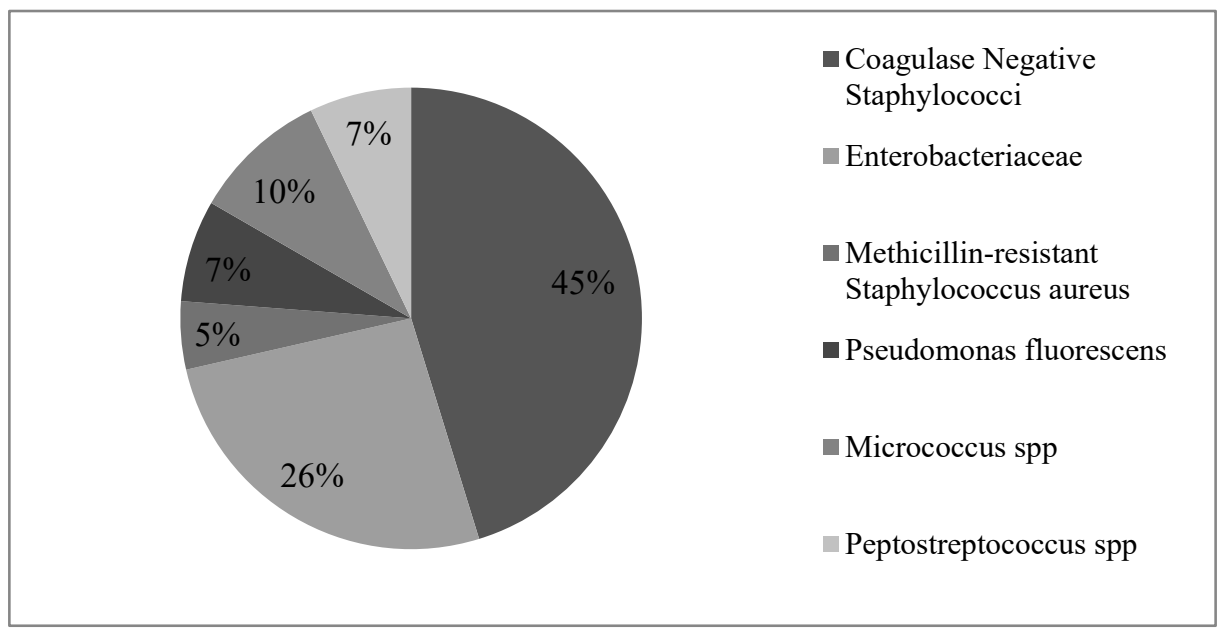

Fig. 3 Distribution of bacteria isolated from surfaces and medical devices.

\section{Discussion}

The environment close to the patient, especially surfaces and medical devices, carrying a resistant bacterium can serve as a second reservoir [26]. The role of medical equipment and surfaces in the indirect transmission of nosocomial pathogens is a subject of many studies [27, 28 ]. There is a debate about the appropriate treatment of hospital surfaces to prevent nosocomial pathogens. Some scientists postulate that cleaning surfaces with non-antimicrobial agents are generally enough [29]. Other scientists prefer the cleaning of surfaces with antimicrobial agents close to patients $[30,31]$. The choice of disinfecting strategy depends on service, technical platform, and pathogens persistence in the surfaces. In this sense, this work aimed to monitor the microbiological quality of the surfaces and medical devices of controlled environmental services (operating room, burns unit, and sterilization service).

Our study showed a contamination rate of $68 \%$. The operating room was the most concerned with a very high contamination percentage of $93 \%$, followed by the Sterilization service $83 \%$ and only $43 \%$ for the Burns department. Several studies have reported contamination in the operating rooms $[32,33,34]$. The level of environmental contamination varies according to the care units and the care techniques used $[3,5,23]$.
In our study, the most contaminated sites were Autoclave, surgical light, and anesthesia cart, followed by bedside tables, the mask of anesthesia, operating tables, instrument tables, and bed rails. This result could be related to the fact that the equipment and surfaces are often in contact with the care staff and patients. Indeed, Méité et al. [35] found that the most contaminated sites were those used by caregivers. Furthermore, medical devices and surfaces with frequent patient contact or caregivers can act as microbial reservoirs and allow infectious agents to contaminate them [36].

The results of our study showed that bacteria represent $98 \%$ of isolates against $2 \%$ of fungi. Our findings are similar to those of Berrada et al. [23]. Identification of fungi did not reveal the presence of either Aspergillus sp or Candida albicans. A study conducted in hematology departments (Paris) showed a predominance of Penicillium sp, Fusarium sp, and Mucorales [37]. Another study showed the similarity between Aspergillus flavus isolated from a surgical site infection and samples taken at an air conditioner used in the operating room [38].

The results of our study showed a predominance of Gram-positive bacteria [67\%]. Lemmen et al. [39] and Berrada et al. reported similar results [23]. The desiccation resistance of Gram-positive versus Gramnegative bacteria [40] could explain this finding. Other studies have shown a high proportion of Gram-negative bacteria compared with Gram-positive [33, 35]. 
Bacterial identification determined Coagulase Negative Staphylococci at $45 \%$. This bacterium colonized the medical devices of hospitals in Iran [41]. Surveillance of the biocontamination of surfaces and equipment carried in a hospital in Fez (Morocco) showed a percentage of $17 \%$ of Coagulase Negative Staphylococci (2015) [17] and 24\% in 2016 [33]. These opportunist bacteria are a cause of nosocomial infections such as endocarditic for Immunocompromised patients [42]. Coagulase Negative Staphylococci can form biofilms and can be resistant to antimicrobial agents [43]. In our study, Methicillinresistant Staphylococcus aureus (MRSA) was isolated from equipment. In a Brazilian university hospital, Staphylococcus aureus was isolated from the surfaces close to the patient [1]. Currently, MRSA is responsible for $50 \%$ of Staphylococcus aureus infections in critical patients in the United States of America [44]. This bacterium represents one of the leading causes of Health-care Associated Infections [39]. MRSA can survive for long periods on surfaces and transmit to patients via caregivers' hands or the environment [45].

Enterobacteriaceae (Escherichia coli, Enterobacter cloacae, and pneumoniae) were present on $26 \%$ of analyzed surfaces. These species have acquired increasing importance as bacteria pathogens and can be involved in many nosocomial infections. Indeed, Klebsiella spp can cause diseases, including pneumonia, urinary tract infections, sepsis, meningitis, and diarrhea [46]. A study carried at Hassan II hospital (Settat Morocco) revealed the presence of Klebsiella pneumoniae at extended-spectrum betalactamases (ESBL) positive in the surfaces and equipment [27]. Escherichia coli can cause (i) the high incidence of morbidity and mortality, (ii) an increase in the associated costs of these various clinical syndromes, (iii) the pathogenic potential of different groups of Escherichia coli strains responsible for intestinal or extra-intestinal diseases and increased resistance to antimicrobials [47]. Concerning Enterobacter cloacae, some strains are ESBL producers, conferring resistance to the third- and fourth-generation cephalosporins [48]. In our study, Pseudomonas fluorescens represents $7 \%$ of isolates. A study was conducted in a hospital in Fes showing Pseudomonas fluorescens on hospital surfaces [13]. Pseudomonas sp is a bacterium that can cause many nosocomial infections [49]. It can survive on inanimate surfaces even for months [50]. According to our results, nosocomial pathogens colonized the surfaces and medical devices. Meunier et al. having observed a high level of HAI where they found that nosocomial microorganisms cover the medical devices close to patients [21]. The appropriate cleaning or disinfection of environmental surfaces [19] and hand hygiene [51] can reduce Health-care Associated Infections (HAI). Several studies have confirmed that cleaning and disinfection were frequently inadequate $[52,53]$. Our study showed the presence of germs of interest nosocomial, which raises the question of the effectiveness of the disinfectants used in these services.

\section{Conclusion}

Our study demonstrably highlights that a wide range of bacteria (Coagulase-negative Staphylococci, Escherichia coli, Enterobacter cloacae, Klebsiella pneumoniae, MRSA, and Pseudomonas fluorescens) can contaminate the surface and medical device. These bacteria increase the risk of HAI. It is important and urgent to assess and strengthen infection prevention practices such as hand hygiene guidelines and recommendations for cleaning and disinfection of surfaces.

\section{Conflicts of interest}

The authors declare that they have no competing interests.

\section{Funding}

No funding sources.

\section{References}

1. K.S. Carvalho M.C. Melo, G.B. Melo, P.P. GontijoFilho. (2007) Hospital surface contamination in wards occupied by patients infected with MRSA or MSSA in a Brazilian university hospital. Aplicada Rev ciênc farm Basi Apl, 28 (2): 159-163

2. A. Kramer, I. Schwebke, and G. Kampf. (2006) How long do nosocomial pathogens persist on inanimate surfaces a systematic review. BMC Infec Di, 6 (130):18

3. AP.Sergent, C. Slekove, J. Pauchot, L. Jeunet, X. Bertrand, D. Hocquet, et al. (2012) Bacterial contamination of the hospital environment during wound dressing change. Orthop Traumatol Surg Res, 98 (4): $441-445$ (2012).

4. JM. Boyce. (2004) New insights for improving hand hygiene practices. Infect Control Hosp Epidemiol, 25 (3) : $187-8$

5. Direction Génèrale de la Santé Direction de l'Hospitalisation et de l'Organisation des Soins. Surveillance microbiologique de l'environnement dans les établissements de santé. http://nosobase.chulyon.fr/recommandations/Ministere Sante/2002 enviro nnement ministere.pdf. [consulted March 11 $1^{\text {th }}$ 2018.]

6. T. Vanzieleghem, M. Delmée. (2019) Les biofilms en milieu hospitalier : quels sont les enjeux pour l'hygiène hospitalière ? noso info, XXXIII (2) : 1-9

7. F. Barbut, D. Neyme. (2006) Les Difficulties D'interpretation Des Controles Microbiologiques Environnementaux. Revue Francophone des Laboratoires, 382 : 27-32. 
8. U. Tattawasart, J.Y.Maillard, J.R Furr, A.D Russell,. Development of resistance to chlorhexidinediacetate and cetylpyridinium chloride in Pseudomonas stutzeri and changes in antibiotic susceptibility. (1999) J Hosp Infec, 42 (3): 219-229.

9. W.A. Rutala, D.J. Weber. (2004) The benefits of surface disinfection. Am J Infect Control., 32 (4): 226231.

10. JA. Otter, GL. (2009) French. Survival of nosocomial bacteria and spores on surfaces and inactivation by hydrogen peroxide vapor. J Clin Microbiol, 47 (1): 205-207.

11. SJ. Dancer. (2009) The role of environmental cleaning in the control of hospital-acquired infection. J Hosp Infect, 73(4): 378-385 .

12. RP. Hobson, FM. MacKenzie, IM. Gould. (1996) An outbreak of multiplyresistant Klebsiella pneumoniae in the Grampian region of Scotland. J Hosp Infect, 33 (4): 249-262.

13. B. Oumokhtar, A. El Ouali Lalami, N. Bnaicha, B. Arhoune, W. Bono. (2017) Environmental surfaces in healthcare setting: a great potential risk of pathogens transmission. Biomed Res, 28 (6) 2398-2401.

14. U Rohr, A Kaminski, M Wilhelm, L Jurzik, S Gatermann, G Muhr. (2009) Colonization of patients and contamination of the patients'environment by MRSA under conditions of single-room isolation. Int $\mathbf{J}$ Hyg Environ Health, 212 (2): 209-215.

15. AC. Shore, AS. Rossney, PM. Kinnevey, OM. Brennan, E. Cremaer, et al. (2011) Enhanced discrimination of highly clonal ST22-methicillinresistant Staphylococcus aureus IV isolates achieved by combining spa, dru, and pulsed-field gel electrophoresis typing data. J Clin Microbiol, 48 (5): 1839-1852.

16. DJ. Weber, WA. Rutala, MB. Miller, K. Huslage, E. Sickbert-Bennett. (2010) Role of hospital surfaces in the transmission of emerging healthcare-associated pathogens: norovirus, Clostridium difficile, and Acinetobacter species. Am J Infect Control, 38 (5 suppl 1): S25-S33.

17. A. EL Ouali Lalami, EL-Akhal F, B. Oumokhtra. (2015) Assessment Of Risk Of Infection Related To Surface Contamination And Equipment In A Hospital In The City Of Fez [Center Of Morocco ]. Int J Pharma Bio Sci, 6 (1): 977 - 983.

18. JM. Boyce. (2007) Environmental contamination makes an important contribution to hospital infection. J Hosp Infect, 65 (2): 50-4.

19. SJ. Dancer. (2014) Controlling Hospital-Acquired Infection: Focus on the Role of the Environment and New Technologies for Decontamination. Clin Microbiol Rev, 27 (4 ): 665-690.

20. S. Galvin, A. Dolan, O. Cahill, S. Daniels, H. (2012) Humphreys Microbial monitoring of the hospital environment:why and how? J Hosp Infect, 82 (3) : 14351 .

21. O. Meunier, C. Hernandez, M. Piroird, R. Heilig, D. Steinbach, A. Freyd. (2005) Prélèvements bactériologiques des surfaces :importance de l'étape d'enrichissement et du choix des milieux de culture. Ann Biol Clin. ; 63 (5) : 481-6.

22. Norme, ISO14698-1. salles propres et environnement apparentés - Maîtrise de la biocontamination- AFNOR. 2004.

23. S. Berrada, G. B. Touimi, L. Bennani, A D. Diarra, B. Oumkhtar, A. ELOuali Lalami, et al, (2017) Exploration microbiologique des surfaces d'un centre d'hémodialyse de la ville de Fès: étude descriptive transversale. Revue Francophone Internationale de Recherche Infirmière, 3 (2) : 120-128.

24. Comité technique national des infections nosocomiales. Surveillance microbiologique de l'environnement dans établissements de santé' - Air, eau et surfaces. 2016. http://nosobase.chu-

lyon.fr/recommandations/cclin_arlin/cclinSudOuest/20 16 Surv microbio environnement CCLIN.pdf.

25. P. Dufresne and S. G. Guy (2018) Identification des Champignons D'importance Médicale, Institut National de Santé Publique du Québec, Québec, Canada,

https://www.inspq.qc.ca/sites/default/files/lspq/identifi cation_champignons importance_medicale.pdf.

26. D. Talon. (1999) The role of environment in the epidemiology of multiresistant bacteria. J Hosp Infect 43(1): 13-17.

27. W. Bouguenoun, S. Bakour, A. A. Bebtorki., C. Albayssari, T. Merad, JM. Rolain. (2016) Molecular epidemiology of environmental and clinical carbapenemase-producing Gram-negative bacilli from hospitals in Guelma, Algeria: Multiple genetic lineages and first report of OXA-48 in Enterobacter cloacae. J Glob Antimicrob Resist, 7: 135-140.

28. S. Natoub, A. Barguigua, S. B Zriouil, N. Baghdad, M. Timinouni, A. Hilali, et al. (2016) Incidence of Extended-Spectrum Be-taLactamase-Producing Klebsiella pneumoniae among Patients and in the Environment of Hassan II Hospital, Settat, Morocco. Adv Microbiol , 6 (3): 152-161.

29. F. Allerberger, G. Ayliffe, M. Bassetti, I. Braveny, A. Bucher, N. Damani , et al. (2002) Routine surface disinfection in health care facilities:should we do it? Am J Infect Contro, 30 (3): 18-319.

30. WA. Rutala, DJ. Weber. (2001) Surface disinfection: should we do it? J Hospl Infec, 48(A): 64S-68S.

31. S. Engelhart, L. Krizek, A. Glasmacher, E. Fischnaller, G. Marklein, M. Exner. (2002) Pseudomonas aeruginosa outbreak in a haematologyoncology unit associated with contaminated surface cleaning equipemet. J Hosp Infec, 52 (2): 93-98. 
32. N. Saouide el ayne, A. Echchelh, A. Chaouch, N. Auajjar, S. Hamama, A. Soulaymani. (2014) Role De L'environnement Hospitalier Dans La Prevention Des Infections Nosocomiales: Surveillance De La Flore Des Surfaces A L'hopital Elidrissi De Kenitra - Maroc. Eur Sci J, 10 (9): 238-247.

33. A. El Ouali Lalami, H. Touijer, F. El-Akhal, M. Ettayebi, N. Benchemsi, S. Maniar, H. (2016) Bekkari. Microbiological monitoring of environment surfaces in a hospital in Fez city,Morocco. J Mater Environ Sci, 7 (1): 123-130.

34. L. Chaoui, R. Ait Mhand, F. Mellouki, and N. Rhallabi. (2019) Contamination of the Surfaces of a Health Care Environment by Multidrug-Resistant (MDR) Bacteria. Int J Microbiol, 7 https://doi.org/10.1155/2019/3236526.

35. S. Méité, C. Boni-Cissé, P. Monemo, AP. Mlan Tanoa, H. Faye-Ketté, H. (2010) Dosso. Surveillance Microbiologique Des Surfaces Au Niveau D'un Établissement Hospitalier De Niveau Tertiaire : Exemple Du Chu De Yopougon, Abidjan, Cote D'ivoire. J Sci Pharm Biol, 11 (1) : 73 _81.

36. LS. Munoz-Price, DJ . Birnbach, DA. Lubarsky, KL. Arheart, Y. Fajardo-Aquino, M. Rosalsky, et al.(2012) Decreasing operating room environmental pathogen contamination through him proved cleaning practice. Infect Control Hosp Epidemiol, 33 (9) : 897-904.

37. Comité consultatif provincial des maladies infectieuses. (2012) Pratiques exemplaires en matière de nettoyage de l'environnement en vue de la prévention et $d u$ contrôle des infections dans tous les établissements de soins de santé. 2ème édition. Toronto : santé publique Ontario.

38. F. Derouin, C. Alberti, A. Bouakline, C. Lacroix, Ribaud P. Corrélation entre la contamination fongique de l'environnement hospitalier et le risque d'aspergillose invasive nosocomiale. Lettr de l'infectiolo. $2002 ; 17$ (2) : 29-34.

39. T M. Diaz-Guerra., E. Mellado, M. Cuenca-Estrella, L. Gaztelurrutia, J I. Villate Navarro, J L .Rodriguez Tudela. (2000) Genetic similarity among one Aspergillus flavus strain isolated from a patient who underwent heart surgery and two environmental strains obtained from the operating room. J Clini Microbiol, 38 (6): 2419-2422.

40. S.W. Lemmen, H. Hafner, D. Zolldann, S. R. (2004) Stanzel Distribution of multi-resistant Gram-negative versus Gram-positive bacteria in the hospital inanimate environment. J Hospl Infec, 56 (3) 191-7.

41. A. Ekrami, A. Kayedani, M. Jahangir, E. Kalantar, M. Jalali. (2011) Isolation of common aerobic bacterial pathogens from the environment of seven hospitals, Ahvaz, Iran. Jundishapur J Microbiol, 4 (2): 75-82.
42. VH. Chu, CW. Woods, JM. Miro, B. Hoen, CH. Cabell, PA. Pappas, J. Federspiel el al. (2008) Emergence of coagulase-negative staphylococci as a cause of native valve endocarditis. Clin Infect Dis, $\mathbf{4 6}$ (2): 232-42.

43. A. Tristan, G. Lina, J. Etienne, F. Vandenesch. ( 2006) Biology and pathogenicity of staphylococci other than Staphylococcus aureus and Staphylococcus epidermidis. In Novick R, Ferretti J, Portnoy D, Rood J Fischetti V.A. Gram-Positive Pathogens. Washington : pp. 572-86.

44. TB. Karchmer, LJ. Durbin, BM. Simonton, BM. Farr. (2002) Cost-effectiveness of active surveillance cultures and contact/droplet precautions for control of methicillin-resistant Staphylococcus aureus. J Hosp Infect, 51 (2): 126-32.

45. JH. Wagenvoort, W. Sluijsman, RJ. Penders. (2000) Better environmental survival of outbreak vs. sporadic MRSA isolates. J Hosp Infec, 45 (3): 231-234.

46. R. Podschun, U. Ullmann. (1998) Klebsiella spp. as nosocomial pathogens epidemiology, taxonomy, typing methods, and pathogenicity factors. Clin Microbiol Rev. 11 (4): 589-603.

47. TA. Russo, JR. (2003) Johnson. Medical and economic impact of extraintestinal infections due to Escherichia coli: focus on an increasingly important endemic problem. Microb Infect, 5 (5): 449-456.

48. DL. Paterson. (2006) Resistance in gram-negative bacteria: Enterobacteriaceae. Am J Infect Control., 34 (5): S20-S28.

49. H. Rüden, P. Gastmeier, FD. Daschner, M. Schumacher. (1997) Nosocomial and communityacquired infections in Germany. Summary of the results of the First National Prevalence Study (NIDEP). Infec, 25 (4): 199-202.

50. S. Panagea, C. Winstanley, MJ. Walshaw, MJ. Ledson, CA. Hart. (2005) Environmental contamination with an epidemic strain of Pseudomonas aeruginosa in a Liverpool cystic fibrosis centre, and study of its survival on dry surfaces. J Hosp Infec, 59 (2): 102-107.

51. A. Al Kadi, S.A. Salati. (2012) Hand Hygiene Practices among Medical Students. Interdiscip Perspect Infect Dis. (6).

52. S. Rouillon, S. Ourdanabia, S. Jamart, C. Hernandez, O. (2006) Meunier. Étude de l'efficacité d'un produit détergent désinfectant pour sols et surfaces sur les souches bactériennes isolées à partir de l'environnement hospitalier. Patho Biolo, 54 (6): 325330 .

53. JH. Han, N. Sullivan, BF. Leas, DA. Pegues, JL. Kaczmarek, CA. (2015) Umscheid. Cleaning Hospital Room Surfaces to Prevent Health Care-Associated Infections. Ann Intern Med 163 (8) : 598-607. 